\title{
POŠTA
}

TELEKOMUNIKÁCIE A

ELEKTRONICKY OBCHOD

\section{VYUŽITIE SOCIÁLNEJ SIETE V MARKETINGU PODNIKU SLUŽIEB}

\author{
Jakub Cíba*
}

\section{1 Úvod}

Sociálne siete $\mathrm{v}$ súčasnosti nie sú žiadnou novinkou, ale vel'mi rozšíreným pojmom, ktorý často zasahuje všetky oblasti každodenného života. V čase ich vzniku boli zamerané najmä na komunikáciu medzi l’ud'mi, avšak s ich rozvojom a rapídnym nárastom používatel'ov sa začali využívat' aj ako nástroj na marketingovú komunikáciu, ked’že prostredníctvom nich majú podniky možnost' oslovovat' vel'ký počet súčasných ale aj potenciálnych zákazníkov. Množstvo podnikov sa pri snahe získat' pozornost' l'udí orientuje na sociálne siete a výnimku netvoria ani poštové podniky. Tie si uvedomili, že prostredníctvom sociálnych sietí sa môžu priblížit' k svojím zákazníkom, oslovovat' ich formou rôznych príspevkov a takisto môžu od nich získavat' spätnú väzbu, ktorá je často krát vel'mi dôležitá pre uspokojovanie potrieb zákazníkov a pre neustále zlepšovanie ponúkaných služieb.

\section{Analýza súčasného stavu využívania sociálnych sietí poštovými podnikmi}

Do analýzy súčasného stavu boli vybraté sociálne siete, ktoré patria medzi najpoužívanejšie a najpopulárnejšie na internete vo svete, ale aj na Slovensku a tie, ktoré najviac využívajú podniky pre svoju marketingovú komunikáciu so svojimi zákazníkmi. Práve tieto sociálne siete po web stránkach naštartovali prechod mnohých podnikov na internet: Facebook, Youtube, Twitter, Google+ a LinkedIn.

Približne $50 \%$ podnikov v Európe používa sociálne siete. Ako môžeme vidiet' na základe nasledujúceho Obrázku 1., podniky využívajú sociálne siete najmä na budovanie svojho imidžu, implementáciu produktov na trh a získavanie názorov a hodnotení od svojich zákazníkov. Vd'aka tomu môžu podniky neustále zlepšovat' svoje poskytované služby. Okrem toho až $29 \%$ podnikov očakáva, že pomocou sociálnych sietí a médií sa môžu zákazníci zapojit' aj do vývoja produktov a podnikových inovácií.

\footnotetext{
* Ing. Jakub Cíba, Žilinská univerzita v Žiline, Fakulta Prevádzky a ekonomiky dopravy a spojov, Katedra spojov, Univerzitná 1, 01026 Žilina, tel. č.: 041/513 3144, e-mail: jakub.ciba@fpedas.uniza.sk
} 


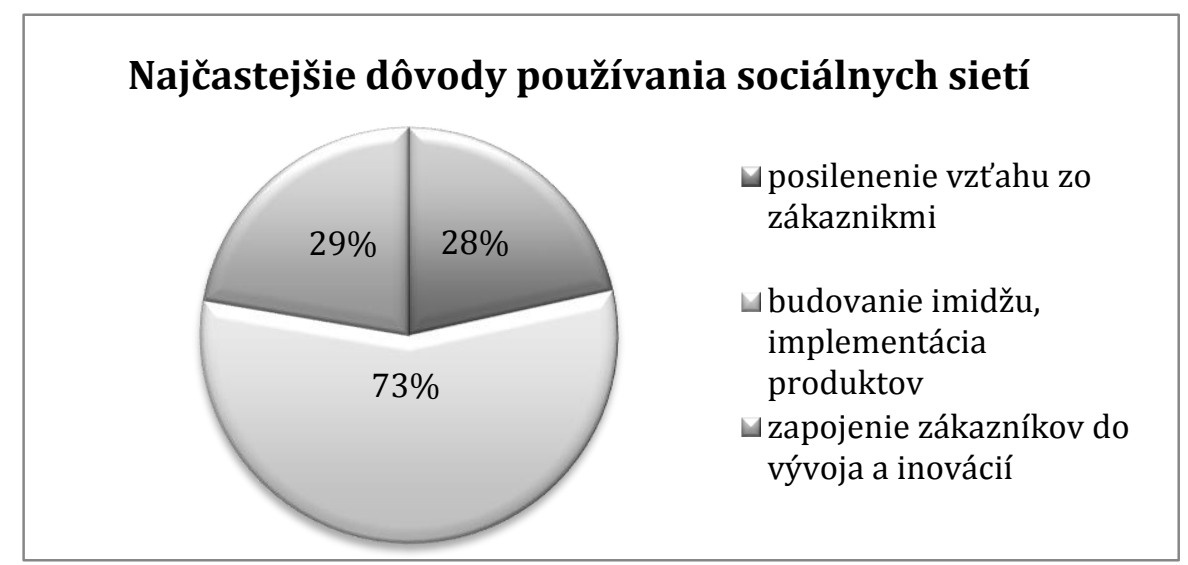

Obrázok 1. Najčastejšie dôvody používania sociálnych sietí (Zdroj: Use of social media by enterprises. [online].[cit. 2014-17-10].Dostupné na internete: <http://epp.eurostat.ec.europa.eu/statistics_explained/index.php/Social_media _statistics_on_the_use_by_enterprises\#Use_of_social_media_by_enterprises $>$. Vlastné spracovanie).

\subsection{Analýza poštových podnikov na Slovensku a v zahraničí}

Pre vykonanie príslušnej analýzy a výskumu v oblasti používania sociálnych sietí, boli vybraté slovenské poštové podniky (Tabul'ka 1.), ktoré sú zaregistrované v registri poštových podnikov SR, s výnimkou fyzických osôb poskytujúcich poštové služby a podnikov, ktoré ukončili svoje podnikanie. Ďalej boli vybraté zahraničné poštové podniky (Tabul'ka 2.), ktoré aktívne pracujú so sociálnymi siet’ami a patria k medzinárodným poštovým podnikom s vel'mi silným zastúpením na svetovom trhu.

Tabul'ka 1. Vybrané poštové podniky na Slovensku

\begin{tabular}{|c|l|}
\hline Poštový podnik & \multicolumn{1}{|c|}{ Popis } \\
\hline Slovenská pošta, a. s. & $\begin{array}{l}\text { Slovenská pošta, a.s., pôsobí na Slovensku od roku 1993, } \\
\text { kedy bola premenovaná z pôvodného štátneho podniku Správa } \\
\text { pôšt a telekomunikácí. V súčasnosti má sídlo v Banskej } \\
\text { Bystrici. }\end{array}$ \\
\hline Kolos s. r. o. & $\begin{array}{l}\text { Poštový podnik Kolos s. r. o. pôsobí v oblasti direct } \\
\text { marketingu a poštových služieb už od roku 1995. V súčasnosti } \\
\text { je členom poprednej skupiny Austrian Post Group a od roku } \\
\text { 2006 aj súčast'ou spoločnosti Österreichische Post AG. }\end{array}$ \\
\hline TNT Express Worldwide spol. s r.o. (TNT & $\begin{array}{l}\text { Podnik TNT Express sa úspešne etabloval na území } \\
\text { Slovenskej republiky v roku 1991. Od roku 1993 však pôsobí } \\
\text { ako samostatný poštový podnik s názvom TNT Express } \\
\text { Worldwide s.r.o.. }\end{array}$ \\
\hline ReMax Courier Service, spol. s r.o. & $\begin{array}{l}\text { ReMax Courier Service, spol. s r.o. pôsobí na slovenskom } \\
\text { trhu od roku 2001. Pri preprave medzinárodných zásielok } \\
\text { do/zo zahraničia podnik spolupracuje s prepravnou } \\
\text { spoločnost'ou Federal Express Corporation ("FedEx } \\
\text { Express"). }\end{array}$ \\
\hline GO4, s. r. o. & $\begin{array}{l}\text { Poštový podnik GO4, s.r.o. vznikol spojením dvoch } \\
\text { existujúcich podnikov, poskytujúcich kuriérske služby (B\&F } \\
\text { Courier a Rockytrans) s finančným partnerom v roku 2005. }\end{array}$ \\
\hline
\end{tabular}




\begin{tabular}{|c|c|}
\hline Direct Parcel Distribution s.r.o (DPD) & $\begin{array}{l}\text { Poštový podnik DPD Slovensko začala svoje podnikanie } \\
\text { v Slovenskej republike v roku } 2002 \text { a stále pokračuje v plnení } \\
\text { svojho zámeru, získat' významný podiel na poštovom trhu } \\
\text { v oblasti vnútroštátnej a medzinárodnej preprave kusových } \\
\text { zásielok. }\end{array}$ \\
\hline Slozak Parcel service s. r. o. (UPS) & $\begin{array}{l}\text { Podnik Slovak Parcel service s.r.o. pôsobí na slovenskom trhu } \\
\text { expresných kuriérskych služieb od roku 1992. Už viac ako } 20 \\
\text { rokov tento poštový podnik zastupuje americkú prepravnú } \\
\text { spoločnost' United Parcel Service (UPS). }\end{array}$ \\
\hline DHL Express (Slovakia), spol. s r. o. & $\begin{array}{l}\text { DHL Express Slovenko s. r. o. patrí medzi prvé medzinárodné } \\
\text { expresné podniky, ktoré začali pôsobit' na území bývalej } \\
\text { československej republiky. V roku } 1986 \text { svoje služby } \\
\text { poskytoval prostredníctvom spoločnosti Čechofracht, a. s.. }\end{array}$ \\
\hline IN TIME, s. r. o. & $\begin{array}{l}\text { Poštový podnik IN TIME, s. r. o. vznikol v roku } 1992 \text { a bol } \\
\text { jedným z prvých podnikov poskytujúcich kuriérske služby na } \\
\text { území Československa. Od roku } 2000 \text { po dohode s poštovým } \\
\begin{array}{l}\text { podnikom Slovak Parcel Service } \\
\text { domestikovanú prepravu. }\end{array}\end{array}$ \\
\hline GEIS Parcel SK s. r. o. & $\begin{array}{l}\text { Prepravná podnik GEIS Slovensko je súčast’ou svetovej } \\
\text { logistickej skupiny Geis Group so sídlom v nemeckom Bad } \\
\text { Neustadtu. }\end{array}$ \\
\hline DER KURIER Slovakia spol. s r. o. & $\begin{array}{l}\text { Poštový podnik DER KURIER Slovakia spol. s r.o., poskytuje } \\
\text { kuriérske služby s medzinárodným aj vnútroštátnym } \\
\text { pôsobením. Podnik začal pôsobit' na Slovensku v roku } 2002 \text {. }\end{array}$ \\
\hline $\begin{array}{c}\text { GLS General Logistics Systems Slovakia } \\
\text { s.r.o. }\end{array}$ & $\begin{array}{l}\text { GLS Slovakia pôsobí na Slovensku od roku 2004. Jeho } \\
\text { hlavnou podnikatel'skou činnost'ou je export expresných } \\
\text { zásielok na území Slovenskej republiky ale aj do krajín } \\
\text { Európskej únie, Turecka, Švajčiarska a Nórska v spolupráci s } \\
\text { GLS General Logistics System. }\end{array}$ \\
\hline Mediaprint-Kapa Pressegrosso, a. s. & $\begin{array}{l}\text { Mediaprint-Kapa Pressegrosso, a.s., má stabilné postavenie na } \\
\text { slovenskom trhu už od začiatku svojho pôsobenia v roku } \\
\text { 1990. Dnes je najuäčši distribútor neperiodickej a periodickej } \\
\text { tlače v Slovenskej republike. }\end{array}$ \\
\hline Železničná spoločnost' Slovensko, a. s. & $\begin{array}{l}\text { Vznik a pôsobenie Železničnej spoločnosti na Slovensku bol } \\
\text { od roku 2005. Jej hlavnou činnostou je prevádzkovanie } \\
\text { osobnej železničnej dopravy ale aj doprava kuriérskych } \\
\text { zásielok na území Slovenskej a Českej republiky. }\end{array}$ \\
\hline
\end{tabular}

Tabul'ka 2. Vybrané poštové podniky v zahraničí

\begin{tabular}{|c|c|}
\hline Poštový podnik & Popis \\
\hline TNT Express Worldwide & $\begin{array}{l}\text { Poštový podnik TNT Express patrí medzi najväčšie expresné } \\
\text { doručovatel'ské podniky. Pokrýva viac ako } 200 \text { krajín na svete } \\
\text { a má vybudované vel'mi silné postavenie na zahraničnom } \\
\text { trhu. }\end{array}$ \\
\hline Direct Parcel Distribution & $\begin{array}{l}\text { Český poštový podnik DPD je v súčasnosti členom } \\
\text { nadnárodnej skupiny GeoPost, ktorá je svetovým lídrom na } \\
\text { poštovom trhu v oblasti zásielok a expresných služieb. }\end{array}$ \\
\hline United Parcel Service (UPS) & $\begin{array}{l}\text { Kuriérsky podnik UPS bol založený v roku } 1907 \text { v Spojených } \\
\text { štátoch amerických. Dnes patrí tento poštový podnik } \\
\text { k najväčším globálnym podnikom a expresným dopravcom } \\
\text { poskytujúcich doručovanie balíkov pomocou } \\
\text { špecializovaných dopráv, logistiky, kapitálu a e commerce } \\
\text { služieb po celom svete. }\end{array}$ \\
\hline DHL & $\begin{array}{l}\text { Poštový podnik DHL začal svoje podnikanie v roku } 1969 . \\
\text { Jeho hlavná podnikatel'ská činnost' bola zameraná na } \\
\text { poskytovanie a výkon kuriérskej služby. }\end{array}$ \\
\hline GEIS Parcel CZ (General Parcel Čechy) & $\begin{array}{l}\text { Český podnik GEIS Parcel zaist'uje balíkovú logistiku na } \\
\text { českom trhu už od roku } 1994 \text { pod obchodnou značkou } \\
\text { General Parcel Čechy. }\end{array}$ \\
\hline
\end{tabular}




\begin{tabular}{|c|c|}
\hline DER KURIER & $\begin{array}{l}\text { Poštový podnik vznikol v roku } 1979 \text { v Nemecku. Je } \\
\text { poskytovatel'om expresných kuriérskych služieb ale aj } \\
\text { logistiky s pridanou hodnotou v rámci celého dodávatel'ského } \\
\text { ret’azca na regionálnej, národnej a medzinárodnej úrovni. }\end{array}$ \\
\hline GLS General Logistics Systems & $\begin{array}{l}\text { GLS General Logistics Systems je medzinárodným podnikom } \\
\text { zameraným na logistiku so sídlom v Amsterdame. Poštový } \\
\text { podnik bol založený v roku } 1999 \text {. }\end{array}$ \\
\hline Česká pošta, š. p. & $\begin{array}{l}\text { Česká pošta ako samostatný podnik začala vznikat' 1. Januára } \\
\text { 1992, kedy sa oddelila od štátneho podniku „Správa pôšt } \\
\text { a telekomunikácií Praha“ samostatná divízia Česká pošta. } \\
\text { O rok neskôr vznikol samostatný štátny podnik „Česká pošta“. }\end{array}$ \\
\hline FIEGE & $\begin{array}{l}\text { FIEGE s.r.o. sa vyvinul pred viac ako } 140 \text { rokmi } \mathrm{z} \text { malého } \\
\text { dopravného a špedičného podniku na jeden } \mathrm{z} \text { najväčších } \\
\text { logistických podnikov v Európe. }\end{array}$ \\
\hline Skynet worldwide express & $\begin{array}{l}\text { Poštový podnik Skynet worldwide express bol založený } \\
\text { v roku } 1972 \text {. V súčasnosti má viac ako } 1000 \text { pobočiek v } 209 \\
\text { krajinách po celom svete, prostredníctvom ktorých ponúka } \\
\text { kompletný rad distribučných služieb. }\end{array}$ \\
\hline Aramex & $\begin{array}{l}\text { Aramex je arabský poštový podnik, ktorý bola založená } \\
\text { v roku } 1982 \text { a patrí medzi popredných svetových } \\
\text { poskytovatel'ov komplexných logistických a dopravných } \\
\text { riešení. }\end{array}$ \\
\hline FedEx & $\begin{array}{l}\text { FedEx vznikol v roku } 1971 \text { pod názvom Federal Expres. } \\
\text { Poštový podnik začal oficiálne fungovat' 17. Apríla } 1973 \text { zo } \\
\text { 14timi malými lietadlami z medzinárodného letiska Memphis, } \\
\text { kedy prepravila } 186 \text { balíkov do } 25 \text { miest v USA. V súčasnosti } \\
\text { je FedEx Express najväčšou expresnou prepravnou } \\
\text { spoločnostou s viac ako 3,9 milióna zásielok za jeden den̆. }\end{array}$ \\
\hline Mediaservis & $\begin{array}{l}\text { Poštový podnik Mediaserivs predstavuje jediného } \\
\text { alternatívneho poštového operátora, ktorý zaistuje svoje } \\
\text { služby na celom území Českej republiky, pomocou } 6500 \\
\text { doručovatel'ov a 150tich kuriérov. }\end{array}$ \\
\hline
\end{tabular}

\section{Ciel' a metodika}

Ciel’om výskumu, prezentovaného $\mathrm{v}$ tomto článku, je analýza stupňa využitia sociálnych sietí v marketingovej komunikácií vybraného poštového podniku. Vzhl'adom $\mathrm{k}$ tomu, že na internete je vel'ké množstvo sociálnych sietí, k bližšej analýze bolo vybratých pät' sociálnych sietí a to tie, ktoré sú najpoužívanejšie na Slovensku a v zahraničí. Na piatich sociálnych siet'ach bola uskutočnená analýza, v akej miere využíva vybraný poštový podnik a jeho konkurencia sociálne siete v oblasti marketingovej komunikácie. Pre vykonanie výskumu v oblasti používania sociálnych sietí, bol vybratý poštový podnik DHL, s. r. o. najmä z toho dôvodu, že má jedno z najväčších zastúpení na sociálnych siet’ach spomedzi všetkých poštových podnikov, a patrí k medzinárodnému poštovému podniku so silným zastúpením na svetom trhu. Prvou úlohou výskumu bolo zistit', v akej miere využívajú poštové podniky vybrané sociálne siete. Druhá úloha, bola zameraná na konkrétne nástroje sociálnych sietí.

\section{Interpretácia výsledkov a výskumu}

Základný ciel' príspevku spočíva v analýze vybraných sociálnych sietí, a ich vplyvu na marketing poštového podniku, najmä na marketingovú komunikáciu. Na splnenie uvedeného ciel'a boli stanovené výskumné otázky. 
Výskumná otázka č. 1: V akej miere využívajú analyzované poštové podniky vybrané sociálne siete?

Tabul'ka 3. Využívanie sociálnych sietí slovenskými poštovými podnikmi

\begin{tabular}{|c|c|c|c|c|c|}
\hline Názov podniku & Facebok & Twitter & Google+ & LinkedIn & Youtube \\
\hline Kolos, s.r.o. & & & & & \\
\hline TNT Express Worldwide, s.r.o & $\bullet$ & & & & $\bullet$ \\
\hline ReMax Courier Service, s.r.o. & & & & & \\
\hline Inspekta Slovakia, a.s. & $\bullet$ & & & & \\
\hline GO4, s.r.o. & $\bullet$ & & & & \\
\hline Cromwell, a.s. & & & & & \\
\hline Direct Parcel Distribution, s.r.o. & $\bullet$ & & $\bullet$ & & $\bullet$ \\
\hline Slovak Parcel Service, s.r.o. & $\bullet$ & & & & \\
\hline DHL, s.r.o. & $\bullet$ & & & & \\
\hline In Time, s.r.o. & $\bullet$ & $\bullet$ & & & \\
\hline Geis Parcel SK, s.r.o. & & & & & \\
\hline Der Kurier Slovakia, s.r.o. & & & & & \\
\hline GLS General Logistic, s.r.o. & $\bullet$ & & & & \\
\hline Systems Slovakia, s.r.o. & & & & & \\
\hline Mediaprint-Kapa Pressergrosso, a.s. & $\bullet$ & & & & \\
\hline Železničná spoločnost' Slovensko, a.s & $\bullet$ & & & & \\
\hline Slovenská pošta, a.s. & $\bullet$ & & & & \\
\hline
\end{tabular}

Tabul'ka 3. zobrazuje používanie najpopulárnejších sociálnych sietí Facebook, Twitter, Google+, LinkedIn a Youtube vybranými slovenskými poštovými podnikmi, ktoré sú zaregistrované v registri poštových podnikov SR, s výnimkou fyzických osôb poskytujúcich poštové služby a podnikov, ktoré ukončili svoje podnikanie.

Podl'a údajov analyzovaných $\mathrm{v}$ Tabul'ke 3. majú slovenské poštové podniky na vybraných sociálnych siet’ach vytvorených iba 17 profilov.

\section{Percentuálny podiel využívania sociálnych sietí slovenskými poštovými podnikmi}

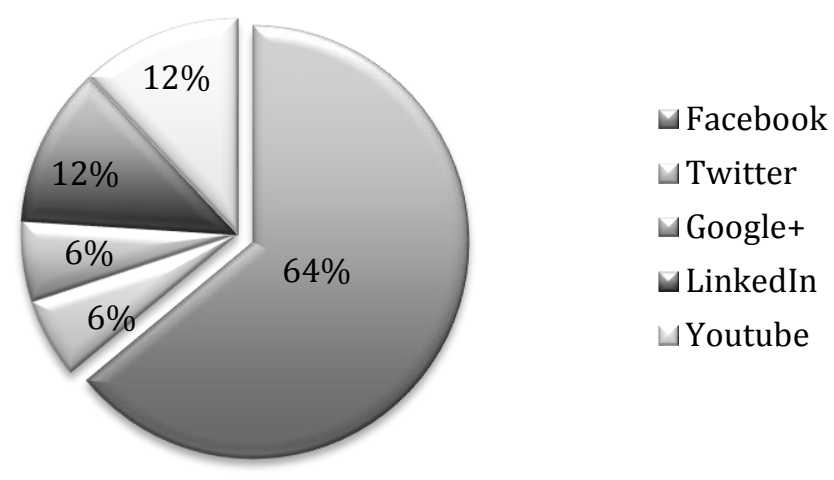

Obrázok 2. Percentuálny podiel využívania sociálnych sietí slovenskými poštovými podnikmi. 
Najväčšie zastúpenie spomedzi všetkých analyzovaných sociálnych sietí na základe Obrázku 2. patrí Facebooku. Na sociálnej sietí Facebook má vytvorený profil až 11 zo 17 poštových podnikov, čo predstavuje v percentuálnom vyjadrení 64\%. Podl'a Obrázku 2. môžeme vidiet' aj zastúpenie ostatných sociálnych sietí, ktoré sú však na Slovensku využívané v ovel'a menšej miere, pretože len $12 \%$ podnikov ( 2 podniky) má zastúpenie na sociálnych siet'ach LinkedIn a Youtube, a len 6\% (1 podnik) na Google+ a Twittery.

Len štyri poštové podniky majú vytvorený profil aj na inej sociálnej sieti ako Facebooku a dokonca iba jeden poštový podnik má svoj profil uverejnený na troch sociálnych siet'ach.

Tabul'ka 4. Využívanie sociálnych sietí zahraničnými poštovými podnikmi

\begin{tabular}{|c|c|c|c|c|c|}
\hline Názov podniku & Facebok & Twitter & Google+ & LinkedIn & Youtube \\
\hline Kolos Netzwerk & $\bullet$ & $\bullet$ & $\bullet$ & $\bullet$ & $\bullet$ \\
\hline TNT Express & $\bullet$ & $\bullet$ & $\bullet$ & $\bullet$ & $\bullet$ \\
\hline Cromwell & & & $\bullet$ & $\bullet$ & \\
\hline Direct Parcel Distribution & $\bullet$ & $\bullet$ & & $\bullet$ & $\bullet$ \\
\hline UPS UK (Slovak Parcel Service) & $\bullet$ & $\bullet$ & $\bullet$ & $\bullet$ & $\bullet$ \\
\hline DHL & $\bullet$ & $\bullet$ & $\bullet$ & $\bullet$ & $\bullet$ \\
\hline Geis Parcel & $\bullet$ & & $\bullet$ & & \\
\hline Der Kurier & $\bullet$ & $\bullet$ & $\bullet$ & & $\bullet$ \\
\hline GLS General Logistics Systems & $\bullet$ & $\bullet$ & $\bullet$ & $\bullet$ & $\bullet$ \\
\hline Česká Pošta & & $\bullet$ & $\bullet$ & & $\bullet$ \\
\hline FIEGE & & & $\bullet$ & $\bullet$ & $\bullet$ \\
\hline Skynet Italy & $\bullet$ & $\bullet$ & & $\bullet$ & \\
\hline Aramex & $\bullet$ & $\bullet$ & $\bullet$ & $\bullet$ & $\bullet$ \\
\hline FedEx Express (Inspekta Remax) & $\bullet$ & $\bullet$ & $\bullet$ & $\bullet$ & $\bullet$ \\
\hline MediaServis & $\bullet$ & $\bullet$ & & & \\
\hline
\end{tabular}

Predchádzajúca tabul'ka (Tabul'ka 4.) zobrazuje používanie vybraných sociálnych sietí - Facebooku, Twitteru, Google+, LinkedIn a Youtubu zahraničnými poštovými podnikmi. Z tabul'ky je viditel'né, že zahraničné poštové podniky využivajú sociálne siete v ovel'a väčšej miere ako tie slovenské. Poštové podniky boli vyberané na základe vel'kého a úspešného zastúpenia na Slovensku ale aj v zahraničí.

Podl'a údajov analyzovaných v predchádzajúce tabul'ke, majú zahraničné poštové podniky vytvorených až 57 profilov na vybraných sociálnych siet’ach.

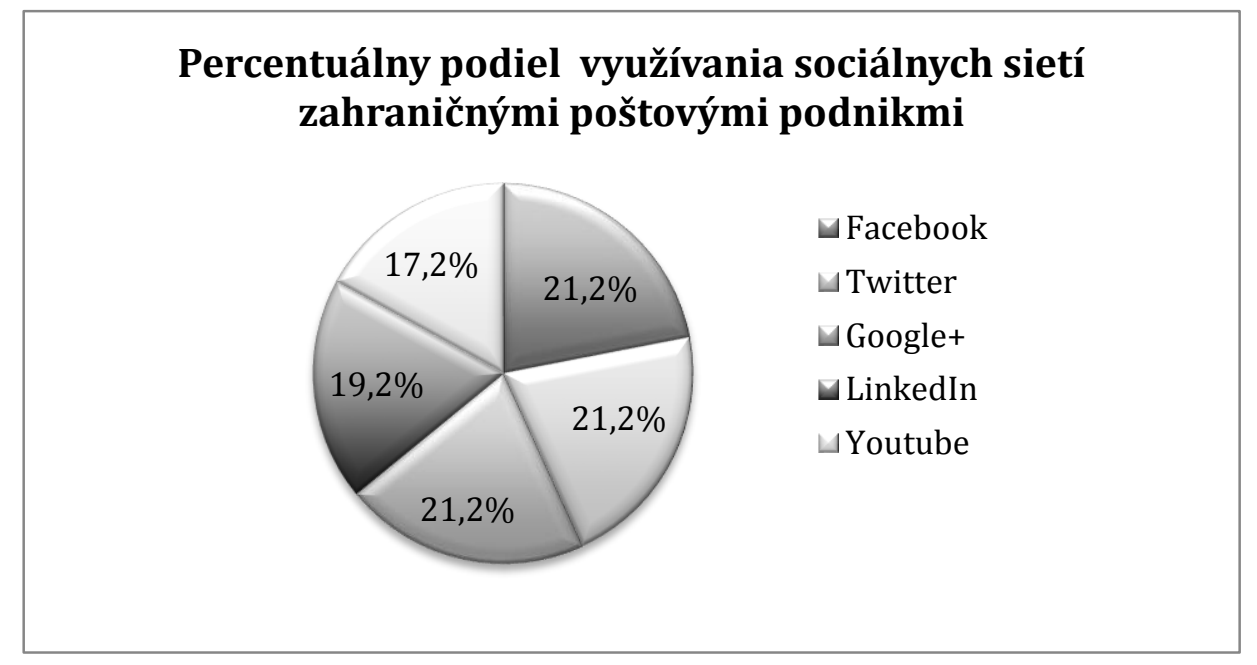


Na Obrázku 3. môžeme vidiet' percentuálne vyjadrenie používania sociálnych sietí jednotlivými zahraničnými poštovými podnikmi. Medzi najviac využívane sociálne siete patria Facebook, Twitter a Google+, čo predstavuje v percentuálnom vyjadrení 21,2\%. Sociálnu siet' LinkedIn využíva 11 podnikov a sociálnu siet' Youtube 10 podnikov, čo predstavuje iba malý rozdiel oproti predchádzajúcim sociálnym siet’am. Zahraničné poštové podniky majú oproti tým slovenským vytvorený profil minimálne na dvoch sociálnych siet’ach, pričom až 7 podnikov má vytvorený svoj profil na všetkých piatich.

Výskumná otázka č. 2: Ktoré nástroje sociálnych sietí je možné aplikovat' v marketingovej komunikácí́?

Tabul'ka 5. Jednotlivé nástroje sociálnych sietí

\begin{tabular}{|l|c|c|c|c|c|}
\hline Nástroje sociálnych sietí & Facebook & Twitter & Google+ & LinkedIn & Youtube \\
\hline Textový príspevok & $\bullet$ & $\bullet$ & $\bullet$ & $\bullet$ & \\
\hline Obrázok & $\bullet$ & $\bullet$ & $\bullet$ & $\bullet$ & \\
\hline Video & $\bullet$ & $\bullet$ & $\bullet$ & $\bullet$ & $\bullet$ \\
\hline Odkaz (link) & $\bullet$ & $\bullet$ & $\bullet$ & $\bullet$ & \\
\hline
\end{tabular}

Analyzovaný poštový podnik DHL na sociálnych siet'ach najčastejšie využíva tie nástroje sociálnych sietí, ktoré možno aplikovat' v marketingovej komunikácií. Medzi tieto nástroje patria: textový príspevok, obrázok, video a odkaz. Tabul'ka 5 zobrazuje, ktoré konkrétne nástroje môže vybraná sociálna siet' využit'. Sociálne siete Facebook, Twitter, Google+ a LinkedIn môžu uverejňovat' svoje príspevky pomocou všetkých štyroch nástrojov avšak sociálna siet' Youtube iba pomocou videa.

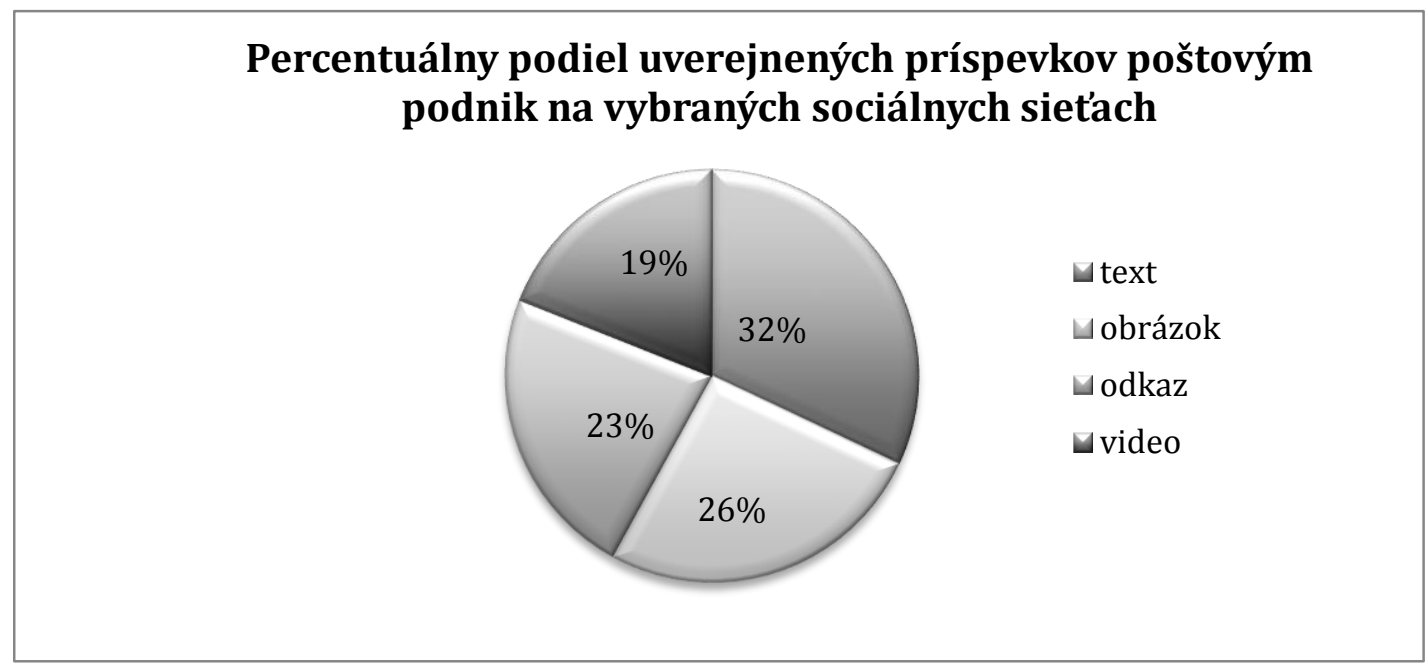

Obrázok 4. Percentuálny podiel uverejnených príspevkov poštovým podnikom DHL na vybraných sociálnych siet'ach.

Uvedený Obrázok 4. zobrazuje percentuálny podiel uverejnených príspevkov v podobe textu, obrázku, videa alebo odkazu, ktoré analyzovaný poštový podnik zdiel'al na všetkých vybraných sociálnych siet'ach v prvom kvartáli roku 2014. Najviac uverejnených 
príspevkov bolo v podobe samotného textu a obrázkov. Celkový počet textových príspevkov predstavoval hodnotu 149 a obrázkov 119 z celkového počtu 460. Príspevky vo forme videí a odkazov majú menšie hodnoty avšak len malým percentuálnym rozdielom sa líšia od predchádzajúcich nástrojov sociálnych sietí.

\section{Záver}

Výskum, ktorý bol uskutočnený na základe dvoch výskumných otázok, bolo zistené, že na vybraných sociálnych siet'ach analyzovaný poštový podnik DHL využíva všetky nástroje marketingovej komunikácie. Medzi najviac používaný nástroj patrí reklama a public relations, menej používanými nástrojmi sú podpora predaja ale aj priamy marketing. Aby však bola marketingová komunikácia poštového podniku efektívna mal by svoje príspevky uverejňovat' v pravidelných časových intervaloch, ktoré zaznamenávajú najvyššiu sledovanost', aby bol neustále v kontakte so svojimi zákazníkmi. Medzi rozhodujúce faktory ovplyvňujúce marketingovú komunikáciu a sledovanost' príspevkov patrí aj vhodne zvolený nástroj sociálnej siete, či už obrázok, text, video alebo odkaz. Výsledky výskumu dokázali, že sociálne siete sú praktickým nástrojom $\mathrm{v}$ oblasti marketingovej komunikácie $\mathrm{z}$ dôvodu neustáleho rastu nových používatel'ov, ale aj nových možností a nástrojov pre podniky, ktoré tieto sociálne siete prinášajú. Sociálne siete sú ideálnym prostriedkom, ktorým sa podniky môžu dostat' bližšie k svojim zákazníkom pomocou vhodne a účinne zvolenej marketingovej komunikácie.

\section{Literatúra}

[1] Social media - statistics. [online]. [cit. 2014-17-10]. Dostupné na internete: <http://epp.eurostat.ec.europa.eu/statistics_explained/index.php/Social_media__statistics_on_the_use_by_enterprises\#Use_of_social_media_by_enterprises>

[2] Use of social media by enterprises.[online].[cit. 2014-17-10]. Dostupné na internete: <http://epp.eurostat.ec.europa.eu/statistics_explained/index.php/Social_media_statistics_ on_the_use_by_enterprises\#Use_of_social_media_by_enterprises>

[3] Sociálne siete na Slovensku. [online].[cit. 2014-17-10]. Dostupné na internete:< http://www.scribd.com/doc/86332262/Socialne-siete-na-Slovensku>

[4] OBERMAJEROVÁ, D.: Využivanie sociálnych sietí v marketingu podniku služieb Bakalárska práca. Žilinská univerzita v Žiline, Žilina 2014. 63. s. 